\title{
The Strategies in Fostering English Enlightenment Education for Pre-school Children in Kindergarten
}

\author{
Huanhuan $\operatorname{Ren}^{1, a^{*}}$, Chi Ma ${ }^{2, b}$ \\ ${ }^{1}$ Teaching and Research Institute of Foreign Languages, Bohai University, Jinzhou 121013, China \\ 2 Jinzhou Institute of Forestry Research, Jinzhou Forestry Bureau, Jinzhou 121013, China \\ arenhuanhuan2014@163.com, ${ }^{\mathrm{b}}$ machi2014@tom.com
}

Keywords: English enlightenment education; Strategy; Pre-school children; Kindergarten

\begin{abstract}
English enlightenment education is gaining momentum in non-English-speaking countries and there are some truths in the fact that it makes sense to implement English enlightenment education in younger EFL learners. Approaches available for English enlightenment among pre-school children in kindergarten could be total physical response, audiovisual education and theory of phonics. Furthermore, practical strategies of English enlightenment for pre-school children in kindergarten are proposed in this thesis, with focus on access to nursery rhymes and animated cartoons, picking up English through picture books and early stage for systematic phonics study, in hope that every learner has the opportunities to learn effortless and grow effectively in English learning at early learning period of life.
\end{abstract}

\section{Introduction}

There are many reasons to learn English and moreover there is a popular belief that children as language learners are superior to adults. It's made evident that English enlightenment education is gaining traction in recent years in non-English-speaking countries. Then how to implement English enlightenment education for pre-school children in kindergarten? What should be paid specially attention whilst instrucitong english among young EFL learners? In order to find the answer of the above questions, this thesis aims at seeking for practical strategies on English enlightenment for pre-school children in kindergarten based on the review of the background of English enlightenment education and approaches available for English enlightenment among pre-school learenrs. This paper is a summary of this research work, which hopefully provides a useful reference for English enlightenment practice among young students.

\section{Background of English Enlightenment Education for Pre-school Children in Kindergarten}

The Rise of English Learning. No one can deny the overwhelming fact that English learning is becoming a fad in today's world. As it's estimated in Economist, "Some 380 million people speak it as their first language and perhaps two-thirds as many again as their second. A billion are learning it, about a third of the world's population are in some sense exposed to it and by 2050, it is predicted, half the world will be more or less proficient in it[1]." Yes, English is everywhere and it is the language of globalization. English is commonly spoken throughout much of the world, that is, English is the language of international communication and business, computers and the Internet, science and technology, even enchantment and recreation through connecting with the film industry. No matter people who are elderly and grey, or people who are teething toddlers, they are given an advantage in living in the world through mastering English language. Or say, learning to speak English well may be the best thing people can do to improve life. It's made evident that learning English will open job prospects and increase standard of living for everyone regardless of people's ethnicity, color, or background.

English Enlightenment Education. Many scholars subscribe to the hypothesis that there is a special period for learning second languages and that when such a period is over, it is difficult to gain 
proficiency in that language[2]. Piaget's theory of cognitive development is groundbreaking as it underpins English learning in most kindergartens and primary schools[3]. In the past, it was believed that babies were without cognition until they were old enough to develop language[4], however, the theory of children's cognitive development changed the way people viewed childhood development. It's further found that, attention, short-term memory, and long-term memory are developing between the ages of 2 and 5; Auditory processing, which is critical for good reading skills, is developing between the ages of 5 and 7; Logic and reasoning also becomes more established during after 5 years of age as a child becomes better able to make connections between ideas[4]. Despite the fact that some scholar believes there is no single magic age for EFL learning, or say second-language learning is not necessarily subject to biological critical periods, it's proved that, on average, there is a continuous decline in ability to learn with age[5]. In light of it, many Chinese pre-school children in kindergarten are engaged to learn $\mathrm{ABC}$ even prior to systematically learning native language.

\section{Theoretical Approaches to English Enlightenment for Pre-school Children in Kindergarten}

Total Physical Response. Total physical response, known worldwide as TPR, was devised by James Asher, a professor emeritus of psychology at San José State University[6]. What's TPR? It's a language teaching method built on the coordination of language and action. In other words, according to TPR, language is attempted to be taught through physical activity. It has enjoyed popularity because of its support by developmental psychology, learning theory, and humanistic pedagogy, as well as on language teaching theory. James Asher developed the total physical response method as a result of his observation of the language development of young children, for example, that learners can understand and react to utterances that are much more complex than those they can produce themselves[7]. It's argued that Asher sees TPR as directed to right-brain learning, whereas most second language teaching methods are directed to left-brain learning [8]. He says that left-hemisphere learning should be avoided, and that the left hemisphere needs a great deal of experience of right-hemisphere-based input before natural speech can occur [7]. Over time, it has been evident that TPR is effective in thousands of language classrooms worldwide.

Audiovisual Education. Audiovisual education or multimedia-based education (MBE) is instruction where particular attention is paid to the audio and visual presentation of the material with the goal of improving comprehension and retention [9]. It encourages instructors to deliver lectures by means of materials that use the senses of sight and hearing to stimulate and enrich learning experiences. More recently, audiovisual aids were widely used during and after World War II by the armed service and the use picture and other visual aids proved to be effective and successful[10]. In the current digital world, audiovisual aids (such as filmstrips, slides, PowerPoint, television educational series and other online materials) have grown rapidly based on the advance in multimedia technologies. It's evident that the visual instruction makes abstract ideas more concrete to the learners through presenting the lesson in more interesting, dynamic, effective way. Learning benefits may accrue by leveraging audiovisual aids in English classroom. It's found by scholars that there is significant difference between the use and non-use of audiovisual material in teaching and learning [11]. It could be seen that audiovisual remains one of the most common methods utilized by instructors especially in language class.

Phonic Instruction. Phonics has been a buzzword in language education scenarios across globe. A great many of scholars abroad have made various researchers on phonics from different perspectives. As for the definition, phonics is regarded is various ways. Generally, phonics was defined as a type of instruction, a kind of relationship between letters and sounds and a method of reading instruction[12]. The majority of scholars considered phonics as a type of instruction, for example Ehri put that phonics is viewed as a method of instruction that teaches students correspondences between graphemes in written language and phonemes in spoken language and how to use these correspondences to read and spell words[13]. According to Allen, however, phonics refers to the set of relationships between sounds and how they can be represented by letters of the alphabet in print; that is, the 
sound-symbol relationships or grapho-phonics[14]. Chen states that phonics is a method of reading instruction that breaks language down into its simple components [15]. Despite different understanding of the concept of phonics, it's found that the phonics principles can be wildly applied to help children with spelling and reading, which is much better than rote memorization and guesswork [16]. Phonics is preceded in a great many of English-speaking countries, such as Canada, Australia, UK, Singapore, and recently there is a global trend toward the incorporation of phonics in EFL instruction among young learners in non-English-speaking countries[12].

\section{Practical Strategies on English Enlightenment for Pre-school Children in Kindergarten}

Access to Nursery Rhymes and Animated Cartoons. There are some truth about the idea that young learners listen attentively if they are not ready to speak (i.e. a sufficient basis in the language has not been internalized). For pre-school children in kindergarten to engage in English enlightenment education, nursery rhymes and animated cartoons are not doubt the first choices and great favorites for younger learners especially in non-English-speaking environment. It's been observed nursery rhymes are a great way to learn how to speak the English language better because they are short enough to memorize after one or two repetitions and the words rhyme makes it easier to pronounce as they sound almost, but not quite, the same[17]. Animated cartoon is a film for the cinema, television or computer screen. Research has showcased the suitability of educational games and animated cartoons to the learning environment when it comes to educating children[18]. The presence of fantasy and colorful pictures in teaching materials promotes the interest of the young learner and reinforces the learning of abstract items in second language instruction[19]. From above, we can see nursery rhymes and animated cartoon have the power to foster children to pick up vocabulary words and promoted their practical usage in real life situations. Please note that repetition is the key to any learning, and learners would be surprised how it will work for themselves.

Picking up English through Picture Books. Every year thousands of picture books are published, illustrated by some of the best artists in the world. A large body of original and authentic picture books have been introduced to foreign countries, or translated into foreign language, so pre-school learners have opportunities to enjoy picture books from the very beginning of learning a language. Picture books features a colorful cast of characters and very basis language vocabulary, which making English learning more enjoyable. Then how to select and use picture books with learners in kindergarten? The picture books should be selected among the popular ones so that young learners are easily drawn and appealed by the selected contents in short text. It's suggested that the language aimed at pre-school should be as simple as possible. As learners in pre-school don't possess the ability to read by themselves, teachers are anticipated to read the story for younger learners in English, sometimes even repeating for several hours running. After children are already familiar with stories, most children can work out how to transfer their individual decoding skills to get meaning form picture books in English. As well, children should not be forced to speak English as it takes time to build up a child's readiness to talk about picture books in English. From above, we can see that sharing a picture book at the stage of pre-school children is just an additional English learning experience that helps children realize that English reading is fun and enjoyable.

Early Stage for Systematic Phonics Study. Phonics is long-time learning among young learners, and pre-school children are in the beginning stage of the journey toward phonics learning. Despite the fact that phonics learning is never an easy job or even a boring job just involving a large amount of relationship between letters and sounds, it can be made fun through various hands-on and interactive activities. It's suggested that letter names and easy letter sounds in English be explicitly and systematically taught to pre-school children. An effective sequence for teaching phonics could build from simple to complex, common to uncommon and known to unknown, which will significantly influence the rate at which students successfully acquire phonics knowledge and skills. As well, the instructor encourages learners to activate as many of their senses as possible through auditory, visual and kinesthetic activities, for example, moving their bodies to make letter shapes, tapping out 
phonemes, writing letters with crayons. All teachers should do is to provide opportunities for students to learn and demonstrate their phonics knowledge in different ways so as to potentially contribute to them developing and extending their vocabularies and general knowledge. And the one-to-one interaction of sharing phonic knowledge can give children added opportunities to develop holistically at their own speed and level. In the meantime, it's recommended that persistent learning and practice should be pursued and sought by students so that they are given more opportunities to apply and consolidate phonics knowledge in practice.

\section{Conclusion}

It's argued that there are some truth in the fact that it makes sense to implement English enlightenment education in younger EFL learners. And English enlightenment education is gaining momentum in non-English-speaking countries. Approaches available for English enlightenment among pre-school children in kindergarten could be total physical response, audiovisual education and theory of phonics. Furthermore, practical strategies on English enlightenment for pre-school children in kindergarten are proposed in this thesis, with focus on access to nursery rhymes and animated cartoons, picking up English through picture books and early stage for systematic phonics study, in hope that every learner has opportunities to learn effortless and grow effectively in English learning at early learning period of life.

\section{Acknowledgements}

This work is part of the project of On Cultivating and Developing Liaoning Scientific Foreign Language Talents with View to Bourdieu' Theory, the project of On Establishing Generative Mechanism of EFL Autonomous Learning Behaviors and Strengthening Development of Learning Field in Ubiquitous Learning Space, and the project of On Constructing Mechanism and Strategies for College English Autonomous Learning Abilities via Mobile Multimedia. This research was supported by the fund of Liaoning Planning of Philosophy and Social Science (Project No. L16CYY001), the fund of Liaoning Provincial Federation Social Science Circles (Project No. 2017lslktyb-019), and the fund of the Thirteenth Five-Year Plan of Education Sciences of Liaoning Province (Project No. JG16DB013).

\section{References}

[1] The Economist, A World Empire by Other Means-The Triumph of English, 22 December, 2001.

[2] J. Moon, Teaching English to Young Learners: Challenging Times, ITB Bandung 5th Conference, Indonesia: ITB Bandung 5th Conference, 2004.

[3] D. L. Schacter, PSYCHOLOGY, Catherine Woods, 2009.

[4] Cognitive Stages for Child Development, Retrieved from the information on http://www.learningrx.com/cognitive-stages-for-child-development.htm

[5] E. Bialystok, K. Hakuta, In other words: The science and psychology of second language acquisition, New York: Basic Books, 1994.

[6] M. Byram, ed., Total Phsyical Response, Routledge Encyclopedia of Language Teaching and Learning. London: Routledge, 2000.

[7] J. C. Richards, T. S. Rodgers, Approaches and Methods in Language Teaching (2nd ed.), Cambridge, New York: Cambridge University Press, 2010.

[8] Total Physical Response. Retrieved from thin information on http://www2.vobs.at/ludescher/total_physical_response.htm 
[9] Audiovisual education. Retrieved from https://en.wikipedia.org/wiki/Audiovisual_education

[10] A. DeBernardes, E. G. Olsen, Audio-visual and community materials - some recent publications, Education Leadership, 1948.

[11]E. O. Ode, Impact of audio-visual (AVs) Resource on teaching and Learning some selected private secondary schools in Makurdi, International journal of Research in humanities, arts and literature, 2014.

[12]Z. Yu, An Application Study of Phonics in English Phonology and Vocabulary Teaching in Primary School, Jiangxi Normal University, 2011.

[13]L. C. Ehri, Systematic Phonics Instruction: Finding of the National Reading Panel, 2003. Retrieved from http://www.standards.dfe.gov.uk/pdfliteracv/lehri-phomcs.pdf, 2011.

[14] R. Allen, First English Phonics, Beijing: Peking University Press, 2008.

[15] Y. J. Chen, Research on the Practice of Phonics in Primary School English Teaching, Xihuan University, 2011.

[16] C. Zhang, A Study on the Application of Phonics in English Tutoring in Primary Schools, Hunan Normal University, 2013.

[17]Learning to Speak English Better Through Nursery Rhymes. Retrieved from the information on http://www.englishpractice.mobi/learning-to-speak-english-better-through-nursery-rhymes/

[18] B. Faloye, An Introductory Course in Theatre and Drama in Education, Abuja: Alpha-Dreams, 2010.

[19]A. Arikan, Environmental Peace Education in Foreign Language Learner's English Grammar Lessons, Journal of Peace Education, 2009. 